\title{
Some Observations of Short-eared Owl, Asio flammeus, Ecology on Arctic Tundra, Yukon, Canada
}

\author{
Donald G. Reid ${ }^{1}$, Frank I. Doyle ${ }^{2}$, Alice J. Kenney ${ }^{3}$, and Charles J. Krebs ${ }^{3}$ \\ ${ }^{1}$ Wildlife Conservation Society Canada, Whitehorse, Yukon Y1A 5T2 Canada \\ ${ }^{2}$ Wildlife Dynamics Consulting Ltd., Smithers, British Columbia V0J 2N0 Canada \\ ${ }^{3}$ Department of Zoology, University of British Columbia, Vancouver, British Columbia V6T 1Z4 Canada
}

Reid, Donald G., Frank I. Doyle, Alice J. Kenney, and Charles J. Krebs. 2011. Some observations of Short-eared Owl, Asio flammeus, ecology on arctic tundra, Yukon, Canada. Canadian Field-Naturalist 125(4): 307-315.

\begin{abstract}
We investigated nesting behavior, food habits, and interspecific interactions of Short-eared Owls (Asio flammeus) within an arctic tundra raptor community on Herschel Island and Komakuk Beach, northern Yukon, Canada. Short-eared Owls were the least common nesting raptor. We found only three nests, all on Herschel Island. All nests were on relatively elevated sites with fairly substantial vegetative cover. All nests failed in the egg stage, from a combination of human disturbance and possible predation by Arctic Fox (Vulpes lagopus) or Red Fox (Vulpes vulpes). Short-eared Owls nested only in years when small rodent densities were at least 4 to 5 individuals per hectare in the spring. Short-eared Owls ate Northern Collared Lemmings (Dicrostonyx groenlandicus), Brown Lemmings (Lemmus trimucronatus), and Tundra Voles (Microtus oeconomus) almost exclusively, without clear selectivity. Peregrine Falcons (Falco peregrinus) killed two adult Short-eared Owls. In northern Yukon, the Short-eared Owl remains an uncommon summer resident and uses the region as a migration route. Spring rodent densities and interspecific predation are prominent limiting factors, and human disturbance also limits nesting success. We recommend restricting access to most tundra areas during periods when the birds are mating, initiating nesting, and incubating eggs. We recommend that human infrastructure be designed so that it cannot support novel nesting (and therefore local range expansion) by other nesting raptors that compete with and prey on Short-earned Owls.
\end{abstract}

Key Words: Short-eared Owl, Asio flammeus, Herschel Island, Komakuk Beach, nesting success, prey selection, raptor community, Herschel Island-Qikiqtaruk Territorial Park, Ivvavik National Park of Canada, Yukon.

The Short-eared Owl, Asio flammeus, is one of the most widespread birds of prey globally. It generally occupies open habitats, such as grasslands, marshes, heaths, and tundra (Wiggins et al. 2006). In Canada, the Short-eared Owl has been classified as a species of special concern by the Committee on the Status of Endangered Wildlife in Canada (COSEWIC), primarily because of population declines apparently resulting from loss or alienation of grassland and marshland habitats (COSEWIC 2008*). In Canada, the Shorteared Owl is on Schedule 3 of the Species at Risk Act.

In northern Canada, habitat loss has been much less than in the south. However, other factors that limit the population size, nesting density, and nesting success of the Short-eared Owl in more southerly regions may also apply in the Arctic. These limiting factors include the abundance of prey (Clark 1975; Priestley et al. 2008); competitive interactions with other predators of rodents, including kleptoparasitism (Clark 1975; Lein and Boxall 1979); nest predation (Wiggins et al. 2006); and mortality resulting from agonistic encounters with other raptors (Murie 1929; Sooter 1942; Killpack 1951; Holt 1992). Populations of the Short-eared Owl congregate in areas with relatively high population densities of small rodents (which are the primary prey of the Short-eared Owl). Clutch size and nesting success also increase with higher rodent densities (Pitelka et al. 1955a; Village 1987; Korpimaki and Norrdahl 1991). The aggregative response to increased numbers of prey appears to result from wide-ranging, nomadic movements (Clark 1975). In addition, some populations of Short-eared Owls, including those nesting in boreal or arctic Yukon, are migratory (Sinclair et al. 2003; Wiggins et al. 2006).

The species has received relatively little attention in arctic regions. Pitelka et al. (1955a, 1955b) studied raptors at Point Barrow on the Arctic Coastal Plain in Alaska, and they found that Short-eared Owls nested only when Brown Lemmings (Lemmus trimucronatus) were at cyclic high densities. Short-eared Owls were completely absent at low densities of Brown Lemmings. Nesting success was poor (only about $13 \%$ of eggs surviving to young leaving the nest), with egg and chick loss resulting from predation by Pomarine Jaegers (Stercorarius pomarinus) coupled with disturbance by humans (Pitelka et al. 1955a, 1955b). Salter et al. (1980) classified Short-eared Owls as "uncommon summer residents" on the Arctic Coastal Plain of northern Yukon, with highest numbers observed during spring migration. Considering the entire Beaufort Sea coastal region, Johnson and Herter (1989*) found that this species was generally uncommon and nested irregularly, notably when small rodent numbers were particularly high. Short-eared Owls have been observed nesting and foraging further north in the Canadian Arctic (Parks Canada Agency 2002*; Therrien 2010) than was confirmed by Wiggins et al. (2006).

From 2007 to 2009, we monitored the abundance and nesting success of all raptors at two Low Arctic sites in northern Yukon, Canada, including observa- 
tions of Short-eared Owl nesting sites, nesting success, food habits, and interspecific interactions. We report these results here to broaden the general understanding of factors limiting the population dynamics of this raptor in the northerly portions of its range and to discuss implications for conservation.

\section{Study Area \\ Terrain}

We gathered data in an area $25 \mathrm{~km}^{2}$ encompassing the eastern end of Herschel Island (Herschel IslandQikiqtaruk Territorial Park) $\left(69^{\circ} \mathrm{N}, 138^{\circ} \mathrm{W}\right)$ and an area $9 \mathrm{~km}^{2}$ on Komakuk Beach, Ivvavik National Park of Canada $\left(69^{\circ} \mathrm{N}, 140^{\circ} \mathrm{W}\right)$. Both sites are on the coast of the Beaufort Sea in northern Yukon, Canada, and both fall within bioclimate zone D or Low Arctic (Walker et al. 2005) (most of the perennial shrub growth is dwarf but sometimes erect up to $50 \mathrm{~cm}$ in height). Elevations range from sea level to $95 \mathrm{~m}$ at Herschel and to $25 \mathrm{~m}$ at Komakuk.

Herschel Island is a well-drained upland plateau, with permafrost-rich clay and mud cliffs falling into the ocean around most of its shoreline. The two dominant upland vegetation types are Cottongrass Tussock Tundra (sedge tussocks composed of 10-20\% cover of Eriophorum vaginatum, Cottongrass) (Smith et al. 1989) and Arctic Willow/Dryas-Vetch (dwarf-shrub heath) (Smith et al. 1989). A few drainages end in lowelevation alluvial fans vegetated with sedge (Carex spp.) meadows with patches of Salix richardsonii (Richardson's Willow) up to $1 \mathrm{~m}$ high (Smith et al. 1989). The coastal plain at Komakuk is quite flat and relatively poorly drained. Sedge and Cottongrass meadows dominate the landscape, interspersed with better drained Cottongrass Tussock Tundra.

\section{Prey}

Northern Collared Lemmings (Dicrostonyx groenlandicus) and Brown Lemmings are the most abundant small rodents on Herschel Island, being more common, respectively, in the more open heath and the more structured tussock tundra. Tundra Voles (Microtus oeconomus) occupy the wetter streamside communities, which have the most vegetative cover. The two lemming species reached peak densities asynchronously, and their combined summer densities were moderately high on upland tundra in 2007 and 2008 (5-19/ha) and quite low in 2009 (2-6/ha) (Krebs et al. 2011). At Komakuk, densities of small rodents were persistently quite low $(<4 / \mathrm{ha})$, with Tundra Voles being most abundant, Brown Lemmings nearly as abundant, and Northern Collared Lemmings virtually absent (Krebs et al. 2011). The most common nesting passerine birds at each site were Lapland Longspur (Calcarius lapponicus) and Savannah Sparrow (Passerculus sandwichensis). The dominant shorebirds were Baird's Sandpiper (Calidris bairdii), Semipalmated Sandpiper (Calidris pusilla), and American Golden Plover (Pluvialis dominica) at Herschel, and Pectoral Sandpiper
(Calidris melanotos) and Red-necked Phalarope (Phalaropus lobatus) at Komakuk.

\section{Other raptors and mammals}

At Komakuk, Peregrine Falcons (Falco peregrinus), Common Ravens (Corvus corax), Rough-legged Hawks (Buteo lagopus), and Parasitic Jaegers (Stercorarius parasiticus) nested in all years, with Peregrine Falcons and Common Ravens relying on the military radar tower for nesting platforms. Arctic Foxes (Vulpes lagopus) denned in 2008, and Least Weasels (Mustela nivalis) were resident in all years. At Herschel, Peregrine Falcons, Rough-legged Hawks, Long-tailed Jaegers (Stercorarius longicaudus), and Sandhill Cranes (Grus canadensis) nested each year, and Snowy Owls (Bubo scandiacus) were present each year but nested only in 2008. Northern Harriers (Circus cyaneus) were transient non-breeders in both areas. Mammalian predators at Herschel in all years included Arctic Fox and Red Fox (Vulpes vulpes) and Least Weasel.

\section{Methods}

Field crews kept records of Short-eared Owl observations as part of a wide range of ecological observations on Herschel Island from late May to mid-September in 2007, 2008, and 2009, and on Komakuk Beach from mid-June to late June in 2008 and 2009 and from mid-August to late August in 2007, 2008, and 2009.

\section{Short-eared Owl nesting sites and nesting success}

To find Short-eared Owl nests, we walked across the tundra through the study areas every two-three days from late May to late June each year (2007, 2008, and 2009 on Herschel Island and 2008 and 2009 at Komakuk). We also performed crepuscular scans from vantage points to observe foraging birds and to locate their resting sites, which we subsequently visited to look for nests. If a nest was located, we avoided the area except for a purposeful visit in mid-July to check on status and extent of hatching and a further visit in mid-August to check on status. To investigate the hypothesis that Short-eared Owls preferentially choose sites providing a combination of greater cover and good local vantage (Pitelka et al. 1955a), we recorded the vegetation type (cover and terrain types in Smith et al. 1989) at each nesting site and its general landscape position.

\section{Small mammals}

Our other studies included mark-recapture population abundance estimates of small rodents on two livetrapping grids of 9 ha each in upland tundra, one grid of 1.8 ha on an alluvial fan, and two index lines of $300 \mathrm{~m}$ each (details in Krebs et al. 2011). To test the hypothesis that there is a threshold prey density in spring that must be reached before Short-eared Owls will initiate nesting, we related the mean density of small rodents from live-trapping in early to mid-June 
to years and sites in which Short-eared Owls initiated nesting.

\section{Short-eared Owl food habits}

Our investigation of diet was based on identification of prey remains in cast pellets. We collected pellets at nests and at perches (locally elevated vantage points within $500 \mathrm{~m}$ of nests) and on repeatedly searched routes. Prey items were identified by molar tooth patterns (Banfield 1974), hair morphology, feather morphology, and occasionally other bones. We tested selectivity for prey species by Short-eared Owls using the forage ratio $(\mathrm{w})$ (proportion in the diet divided by proportion available, based on estimates of rodent abundance) as a selection index and the $G$-test statistic to assess the significance of selection (after Krebs 1999).

\section{Interspecific interactions}

To investigate potential competitive effects on nest spacing, we mapped the locations of all raptor nests in the study areas to measure distances between nests. To investigate potential interspecific predation, we identified prey remains at the nests of other raptors, and we were always on the lookout for kill sites.

\section{Results}

We observed Short-eared Owls most frequently during their spring (late May) and autumn (September) migrations. The observations during migration were all made on Herschel Island, as we did not visit Komakuk at those times. The owls were particularly attracted to the relatively high densities of Brown Lemmings (approximately 10/ha in spring 2007 and approximately 31/ha in September 2008) on an alluvial fan (Pauline Cove). Up to 5 Short-eared Owls hunted this sedge meadow habitat at one time between mid-September and late September. They occasionally cached Brown Lemmings before foraging again. Signs in fresh snow (30 September 2008) indicated that a Short-eared Owl had killed and partially consumed a juvenile Glaucous Gull (Larus hyperboreus). The latest date we observed a Short-eared Owl was 29 September (in 2008). Apart from these observations during migration, we rarely observed Short-eared Owls except in association with known nests. It appeared that a few nonbreeders stayed on the mainland coastal plain through the summer, judging by occasional observations at Komakuk, where we found no evidence of nesting.

\section{Nesting}

We found only three Short-eared Owl nests during the three years, two in 2007 and one in 2008, all on Herschel Island (Table 1). The nests were in a variety of vegetation types, but all were in association with taller grass (Arctagrostis latifolia, Polargrass) or tussocks (Eriophorum vaginatum) that provided some cover. The nests were all on relatively high landscape positions that offered wide views (Table 1). Nest cups had some dead grass stalks that provided rudimentary bedding.

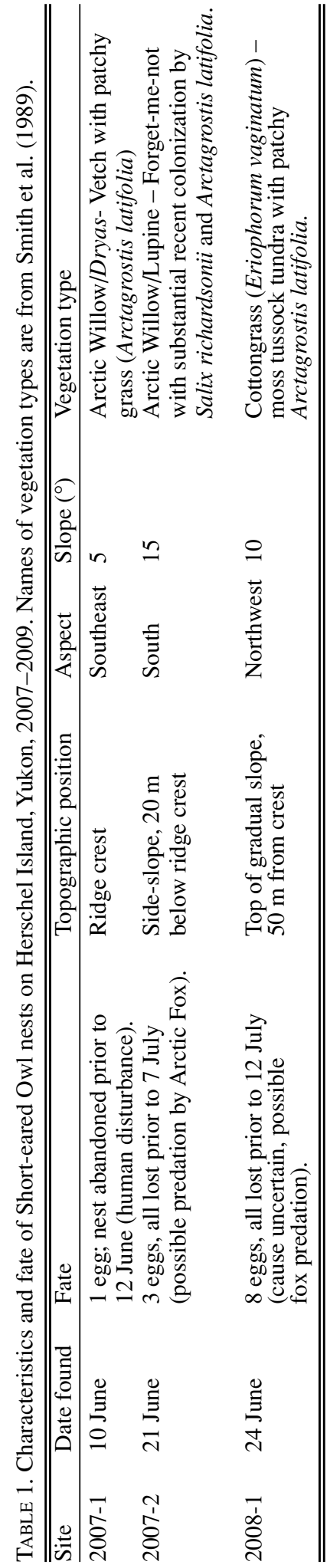


All three nests failed during the egg stage. One failed very early, with only one egg, and abandonment appeared to have resulted from our disturbing the incubating female at this sensitive time. The most likely nest predator (based on frequency of activity near nests and evidence) was foxes (two nests predated in 2007 by Arctic Fox and one nest predated in 2008 by either Arctic or Red Fox). When the two nests were checked in mid-July, the nests had no eggs or egg fragments, no downy feathers, and no pellets. Other potential predators included Sandhill Crane, Wolverine (Gulo gulo), and Grizzly Bear (Ursus arctos). However, the cause of nest failure was unclear, and human disturbance may have influenced success of all three nests.

Densities of small rodents in early to mid-June varied considerably among years and sites, but we found evidence of Short-eared Owls nesting only in years with the highest rodent densities (Figure 1). There was no evidence of nesting at Komakuk, where rodent densities were persistently low. Our limited data suggest a minimum threshold density of approximately 4 to 5 lemmings per hectare before the owls will initiate nesting (Figure 1).

\section{Food habits}

We collected 111 pellets for diet analyses (21 in 2007, 60 in 2008, and 30 in 2009), all from Herschel Island. Nearly every pellet had only one prey type. Short-eared Owls consumed small rodents almost exclusively, with a few passerine birds taken in 2008 (Figure 2). The Short-eared Owls successfully hunted all three small rodent species, foraging across the full diversity of tundra types on the island. They took Northern Collared Lemmings more often than other species, but the availability of each species varied among years. Our assessment of Short-eared Owls' selection of the three small rodent species (Table 2) shows no statistically significant selection of one prey species over another in any of the three years, but there was a tendency to select Tundra Voles in 2007 and 2008. Short-eared Owls did not select for Northern Collared Lemming, the species living in the more open tundra habitats, but the owls were able to forage successfully for Tundra Voles, which inhabit the more structurally complex valley floor habitats.

\section{Interspecific interactions}

Short-eared Owls nested in a summer raptor community on Herschel Island that included Snowy Owl, Peregrine Falcon, Rough-legged Hawk, and Long-tailed Jaeger. Snowy Owls nested only in 2008 but were frequently present, especially early in the summer, in other years. The other raptors nested in each of the three years. Peregrine Falcons and Rough-legged Hawks nested on mud cliffs mostly along the coastline, and therefore at the periphery of the study area. Snowy Owls, Short-eared Owls, and Long-tailed Jaegers partitioned the inland space. Short-eared Owls were the least common nesting raptor, except in 2007, when Snowy Owls did not nest on Herschel Island.
In 2007, the mean distance from a Short-eared Owl nest to the nearest nest of another raptor (including the other Short-eared Owl nest) was $538 \mathrm{~m}$. The same year, the mean distance from any raptor nest (excluding the two Short-eared Owl nests) to the nearest raptor nest (including the two Short-eared Owl nests) was $583 \mathrm{~m}$. In 2008, mean distance from the Short-eared Owl nest to the nearest nest of another raptor was $2000 \mathrm{~m}$. The same year, the mean distance from any raptor nest (excluding the Short-eared Owl nest) to the nearest raptor nest (including the Short-eared Owl nest) was $768 \mathrm{~m}$. With our low sample sizes, we could not reject the hypothesis that the Short-eared Owls nested closer to other raptors in 2007 (Mann-Whitney $U=8.5$, $P>0.20$ ) or 2008 (Mann-Whitney $U=14, P=0.10$ ). However, the single nest in 2008 was relatively isolated compared to those of other species. In 2007, the nearest nesting neighbours were Long-tailed Jaegers, and in 2008 Snowy Owls.

We did not observe any agonistic encounters between the Short-eared Owls and other nesting raptors. However, in July 2007 we found two carcasses of Shorteared Owls. We judge these to have been killed by Peregrine Falcons, based on the close proximity of the kill sites $(<300 \mathrm{~m})$ to active Peregrine Falcon nests and the presence of whitewash, plucked feathers, and carcass remains, all within a few square metres. FD found remains of Short-eared Owls at a number of Peregrine Falcon nests along the Mackenzie River in 2005, including three individuals at one nest. We observed a Short-eared Owl attacking a Sandhill Crane within $10 \mathrm{~m}$ of a Short-eared Owl nest, but we have no direct evidence that the Sandhill Crane had found the nest. This nest subsequently lost two eggs from the clutch, but no egg remains were left behind. On another occasion, we observed a pair of Short-eared Owls (probably the same pair) chasing and attacking a lone Red Fox.

\section{Discussion}

Our findings confirm some previous knowledge of Short-eared Owl ecology in the northern Yukon and the Low Arctic tundra. This is an uncommon raptor, using the region in migration, sporadically for nesting, and uncommonly as non-breeding summer range. We confirm the observation made by Salter et al. (1980) that the Short-eared Owl is an "uncommon summer resident". As reported by Pitelka et al. (1955a), nesting is limited to years with high small rodent prey densities, egg laying occurs in mid-June, and the birds choose nest sites with relatively good vantage yet relatively high vegetative cover. The maximum clutch size we observed $(n=8)$ is the same as that reported from Alaska (Pitelka et al. 1955a). Our findings that the Short-eared Owls abandon nests when disturbed early in laying and that they prey almost exclusively on small rodents reinforce the information of Pitelka et al. (1955b).

Our findings also augment previous knowledge. They suggest that a minimum prey density of 4 to 5 


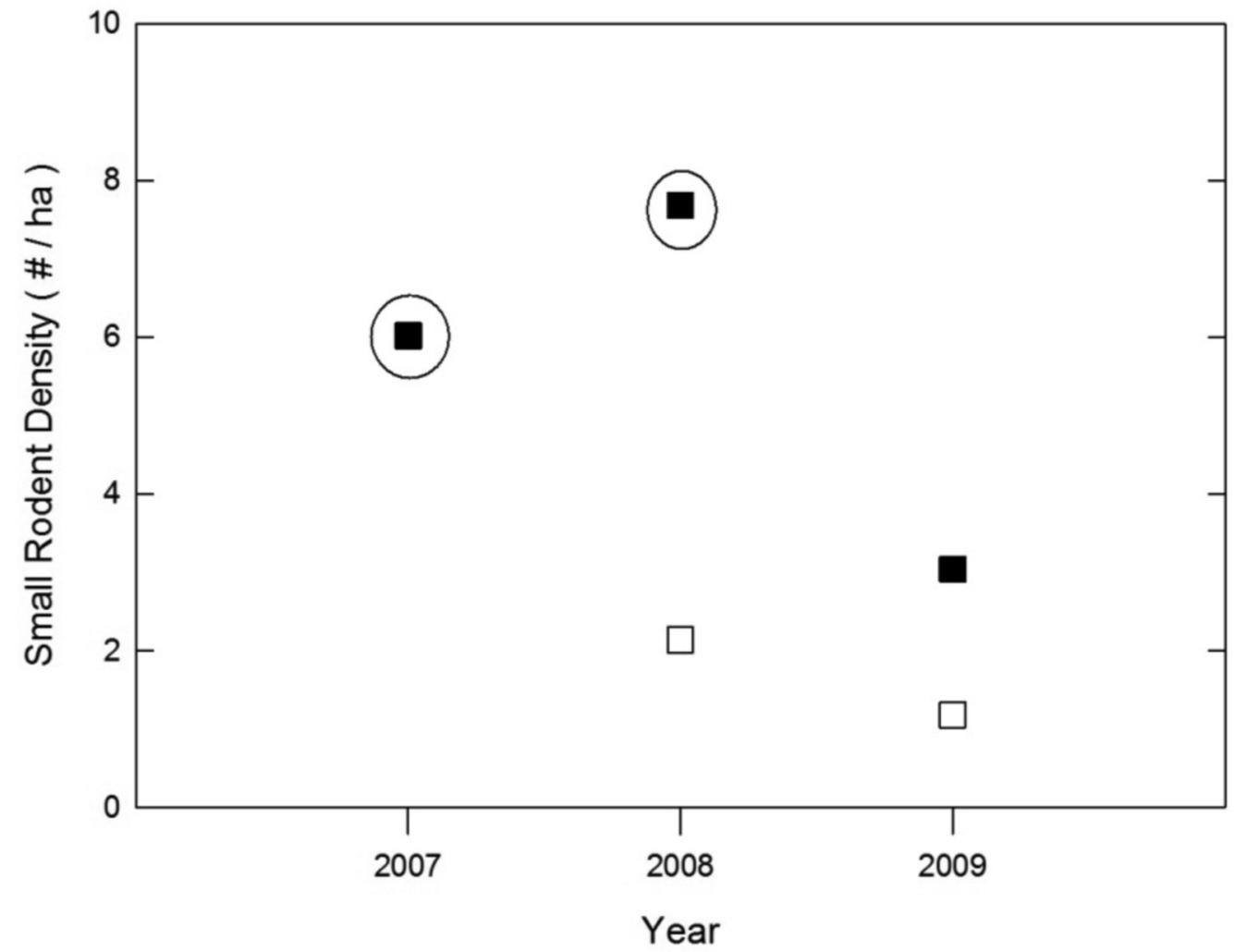

FIGURE 1. Combined density of small rodents (lemmings and voles) in early June to mid-June on Herschel Island in 2007 , 2008, and 2009 (black squares) and on Komakuk Beach in 2008 and 2009 (open squares), plotted for each of the three years. Circled data points indicate springs when Short-eared Owls nested (i.e., 2007 and 2008 on Herschel Island).

small rodents (lemmings and voles) per hectare is necessary before Short-eared Owls will start nesting, although this hypothesis needs further testing. We found that this raptor is able to take advantage of all three resident small rodent species, even preying relatively heavily on Tundra Voles, which occupy the wetter habitats with the tallest and thickest growth of graminoid and willow (Salix spp.) vegetation.

We have some indication that Short-eared Owl nests are susceptible to predation, with foxes and Sandhill Cranes being potential predators. Since Sandhill Cranes are known to hunt lemmings (both Dicrostonyx and Lemmus) and young birds on breeding grounds in the Arctic (Reed 1988; Tacha et al. 1992) and can take Canada Goose (Branta canadensis) eggs (Hoffman 1980), Sandhill Cranes need to be considered as potential nest predators.

We suggest that Short-eared Owls nest infrequently in northern Yukon primarily because of low prey abundance and agonistic interactions with other raptors. Our studies indicate that lemmings and voles persist at low densities $(<4 / \mathrm{ha})$ on the mainland coastal plain but exceed this threshold more frequently on Herschel
Island (Krebs et al. 2002, 2011). Consequently, Shorteared Owls may not find sufficient prey on the mainland coastal plain in most years to support nesting. Our results, and observations by Talarico and Mossop (1986*), indicate that Short-eared Owls nest on Herschel Island only in years with higher prey abundance. The same pattern applies to Snowy Owls, with no recorded nesting on the mainland coastal plain and only intermittent nesting on Herschel Island (Salter et al. 1980; Talarico and Mossop 1986*; Sinclair et al. 2003).

When prey are abundant, Short-eared Owls have to find nesting territories at the same time as Snowy Owls and jaeger species (which also congregate in areas with high rodent densities in spring) (Pitelka et al. 1955b) are selecting nesting sites. Interspecific competition for nesting territories may limit Short-eared Owl nesting in some years. In addition, Peregrine Falcons, Gyrfalcons (Falco rusticolus), and Snowy Owls are known to kill adult Short-eared Owls during the nesting season (Murie 1929; Wiggins et al. 2006), and Peregrine Falcons can limit the survival of adult Short-eared Owls on Herschel Island. 
The risk of intra-guild predation is increasingly recognized as a prominent process structuring ecological communities of raptors, through direct mortality, habitat and temporal segregation, or distributional changes (Sergio and Hiraldo 2008). Killer species always weigh more than victim species, by a ratio of at least 1.13:1.0 (Sergio and Hiraldo 2008). The ratio for Peregrine Falcons (tundrius subspecies) and Short-eared Owls is approximately 2.0:1.0 (White et al. 2002; Wiggins et al. 2006). On the Yukon coastal plain, Peregrine Falcons nest on structures such as radar towers. Gyrfalcons nest in the British Mountains and the Barn Range (Barn Mountains) and they forage on the plain (Sinclair et al. 2003). The risk of intra-guild predation may result in Short-eared Owls avoiding nesting in landscapes with falcons (i.e., much of the coastal plain).

Although nesting opportunities may be limited for the Short-eared Owl in northern Yukon, the region is clearly an important migratory route for these birds (Salter et al. 1980). Our observations indicate that alluvial fan habitats on Herschel Island can be particularly valuable for migratory Short-eared Owls and some other raptors, such as Northern Harrier.

The ecological relationship between Short-eared Owls and Snowy Owls is particularly interesting, as they have similar life histories, responding in an aggregative fashion to high prey densities, having fairly large clutches, and feeding on small rodents. They differ in their hunting tactics, however. The Short-eared Owl is an "active search" raptor (Jaksic and Carothers 1985). It can catch prey in the thicker vegetation because it hunts on the wing, quartering close to the ground, sometimes hovering, using hearing and sight to locate prey at short range, and readily dropping from the air onto prey (Wiggins et al. 2006). This foraging behaviour contrasts with that of the Snowy Owl, which is a "sit-and-wait" raptor, hunting primarily from a perch and relying mostly on vision to detect prey at relatively long distances, followed by direct chase (Jaksic and Carothers 1985; Parmalee 1992).

In a warming climate, cover of woody perennials and some forbs is increasing on Herschel Island, and the vegetation is becoming structurally more complex with an influx of Polargrass and increased spread and height in willows (Salix glauca, S. pulchra, and $S$. richardsonii) (Kennedy et al. 2001; Myers-Smith et al. 2011). These trends will provide more cover for small rodents, likely reducing the foraging success of Snowy Owls. We believe the vegetation changes will benefit the Short-eared Owl and likely the Northern Harrier, because these species can forage successfully in habitats with much heavier growth than is currently present on most of Herschel Island and because the intensity of competition from Snowy Owls is likely to decline.

\section{Conservation implications}

We conclude that Short-eared Owls in arctic Yukon are primarily limited by natural factors, most notably

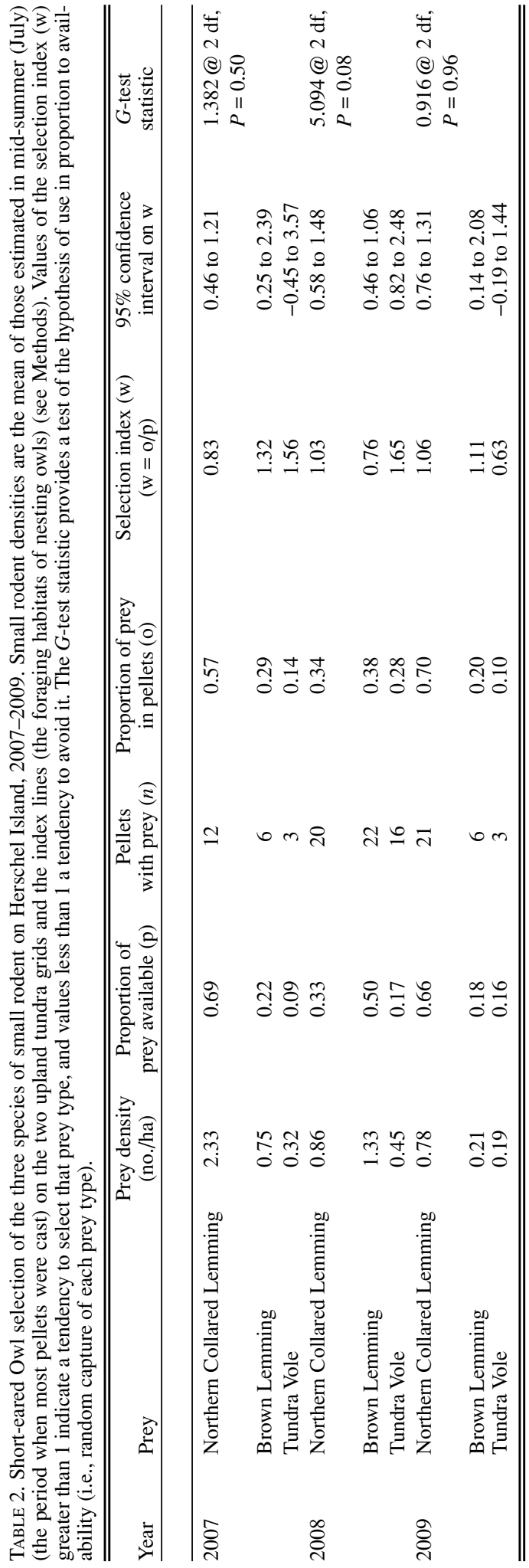




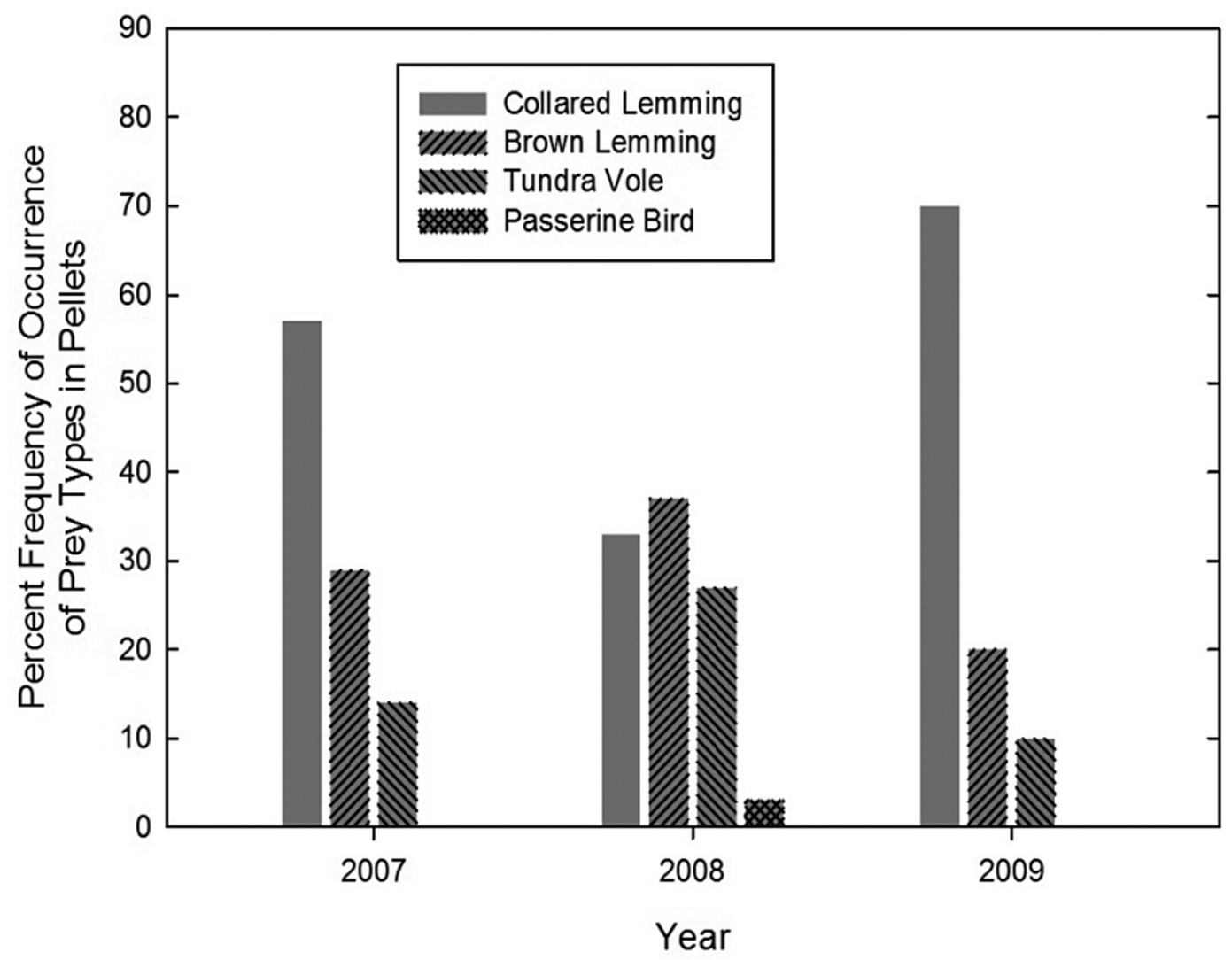

FIGURE 2. Food habits of Short-eared Owls on Herschel Island, Yukon, expressed as the percentage frequency of occurrence of different prey types in cast pellets.

low prey abundance and adult mortality from intraguild predation. Human disturbance can limit nesting success. Nesting opportunities are probably uncommon for this owl in the region, so human activities need to be closely managed to avoid any reduction in those opportunities. We recommend restrictions on human access to the tundra from late May to late June so as to reduce the risk of Short-eared Owls abandoning nests following disturbance. Prohibiting access would be to the benefit of all birds that nest on the tundra and would be particularly valuable in protected areas like Herschel Island-Qikiqtaruk Territorial Park and Ivvavik National Park.

We also recommend that any new structures built for transportation, communications, industrial, or other applications be designed to minimize their suitability as nesting platforms for falcon species or for Roughlegged Hawks and Common Ravens, which might build nests that would subsequently be used by falcons. Some of the northern Yukon tundra is currently not within the breeding territories of falcon species. For Short-eared Owls to prosper, it needs to remain that way.
We recommend more extensive identification (through spring and fall surveys) and protection of high-quality migratory foraging habitats, such as those we already identified. These are protected in Herschel Island-Qikiqtaruk Territorial Park and Ivvavik National Park, but not elsewhere along the coast. We also recommend more monitoring of small rodent populations in the Arctic to better understand their population dynamics, which are key to the conservation of the Short-eared Owl and many other predators.

\section{Acknowledgements}

This research was funded under the International Polar Year Program (Arctic Wildlife Observatories Linking Vulnerable Ecosystems) by Indian Affairs and Northern Development Canada (now Aboriginal Affairs and Northern Development Canada), the Inuvialuit Final Agreement Wildlife Implementation Fund, and Wildlife Conservation Society Canada. Logistical support was provided by the Polar Continental Shelf Program (Natural Resources Canada), Aurora Research Institute in Inuvik, and staff of Herschel Island-Qik- 
iqtaruk Territorial Park in Inuvik. We thank Wendy Nixon of the Canadian Wildlife Service (Environment Canada) and Christian Bücher and staff of the Western Arctic Field Unit of the Parks Canada Agency for sponsoring the application to the Inuvialuit Wildlife Implementation Fund. We thank David Mossop, Alistair Blachford, Michael Nelligan, Scott Gilbert, Maria Leung, Polly Madsen, Liz Hofer, Edward McLeod, Sam McLeod, and Lee-John Meyook for assistance in the field.

\section{Documents Cited (marked * in text)}

COSEWIC. 2008. COSEWIC assessment and update status report on the Short-eared Owl Asio flammeus in Canada. Committee on the Status of Endangered Wildlife in Canada, Ottawa. vi + 24 pp. http://www.registrelep-sararegistry.gc. ca/document/default_e.cfm?documentID=1646. (Accessed February 2012).

Johnson, S. R., and D. R. Herter. 1989. The birds of the Beaufort Sea. BP Exploration Inc., Anchorage, Alaska, USA.

Parks Canada Agency. 2002. Annual report of research and monitoring in the National Parks of the western arctic. Parks Canada Agency, Western Arctic Field Unit, Inuvik, Canada. http://www.pc.gc.ca/eng/docs/v-g/rs-rm2002/sec4 /page3.aspx. (Accessed February 2012).

Talarico, D., and D. Mossop. 1986. A three-year summary of avifauna research on Herschel Island: An interim report for use in Park management and interpretive programs. Yukon Department of Renewable Resources, Whitehorse, Canada. 71 pages.

\section{Literature Cited}

Banfield, A. W. F. 1974. The mammals of Canada. University of Toronto Press, Toronto, Ontario, Canada.

Clark, R. J. 1975. A field study of the Short-eared Owl, Asio flammeus (Pontoppidan), in North America. Wildlife Monographs 47: 1-67.

Hoffman, R. 1980. Sandhill Cranes prey on Canada Goose eggs. Wilson Bulletin 92: 122.

Holt, D. W. 1992. Notes on Short-eared Owl (Asio flammeus) nest sites, reproduction and territory sizes in coastal Massachusetts. Canadian Field-Naturalist 106: 352-356.

Jaksic, F. M., and J. H. Carothers. 1985. Ecological, morphological, and bioenergetic correlates of hunting mode in hawks and owls. Ornis Scandinavica 16: 165-172.

Kennedy, C. E., C. A. S. Smith, and D. A. Cooley. 2001. Observations on change in the cover of Polargrass, Arctagrostis latifolia, and Arctic Lupine, Lupinus arcticus, in upland tundra on Herschel Island, Yukon Territory. Canadian Field-Naturalist 115: 323-328.

Killpack, M. L. 1951. Short-eared Owl eaten by Horned Owl. Condor 53: 262.

Korpimaki, E., and K. Norrdahl. 1991. Numerical and functional responses of Kestrels, Short-eared Owls and Longeared Owls to vole densities. Ecology 72: 814-826.

Krebs, C. J. 1999. Ecological methodology. Benjamin Cummings, Menlo Park, California, USA.

Krebs, C. J., A. J. Kenney, S. Gilbert, K. Danell, A. Angerbjörn, S. Erlinge, R. G. Bromley, C. Shank, and S. Carriere. 2002. Synchrony in lemming and vole populations in the Canadian Arctic. Canadian Journal of Zoology 80: 1323-1333.
Krebs, C. J., D. G. Reid, A. J. Kenney, and B. S. Gilbert. 2011. Fluctuations in lemming populations in north Yukon, Canada, 2007-2010. Canadian Journal of Zoology 89: 297306.

Lein, M. R., and P. C. Boxall. 1979. Interactions between Snowy and Short-eared Owls in winter. Canadian FieldNaturalist 93: 411-414.

Murie, O. J. 1929. Nesting of the Snowy Owl. Condor 31: 3-12.

Myers-Smith, I. H., D. S. Hik, C. E. Kennedy, D. A. Cooley, J. F. Johnstone, A. J. Kenney, and C. J. Krebs. 2011. Expansion of canopy forming willows over the 20th century on Herschel Island, Yukon Territory, Canada. Ambio 40: 610-623.

Parmalee, D. F. 1992. Snowy Owl (Bubo scandiacus). The Birds of North America Online. Edited by A. Poole. Cornell Lab of Ornithology, Ithaca, New York. http://bna.birds .cornell.edu/bna/species/010. (Accessed February 2012).

Pitelka, F. A., P. Q. Tomich, and G. W. Treichel. 1955a. Breeding behavior of Jaegers and Owls near Barrow, Alaska. Condor 57: 3-18.

Pitelka, F. A., P. Q. Tomich, and G. W. Treichel. 1955 b. Ecological relations of Jaegers and Owls as lemming predators near Barrow, Alaska. Ecological Monographs 25: 85-117.

Priestley, D. L., G. L. Holroyd, and C. E. Priestley. 2008. Short-eared owl invasion at Beaverhill Lake, Alberta, winter 2005-2006. Blue Jay 66: 131-138.

Reed, J. R. 1988. Arctic adaptations in the breeding biology of Sandhill Cranes, Grus canadensis, on Banks Island, Northwest Territories. Canadian Field-Naturalist 102: 643648.

Salter, R. E., M. A. Gollop, S. R. Johnson, W. R. Koski, and C. E. Tull. 1980. Distribution and abundance of birds on the Arctic coastal plain of northern Yukon and adjacent Northwest Territories, 1971-1976. Canadian FieldNaturalist 94: 219-238.

Sergio, F., and F. Hiraldo. 2008. Intraguild predation in raptor assemblages: a review. Ibis 150 (Suppl. 1): 132-145.

Sinclair, P. H., W. A. Nixon, C. D. Eckert, and N. L. Hughes. 2003. Birds of the Yukon Territory. UBC Press, Vancouver, Canada.

Smith, C. A. S., C. E. Kennedy, A. E. Hargrave, and K. M. McKenna. 1989. Soil and vegetation survey of Herschel Island, Yukon Territory. Yukon Soil Survey Report No. 1. LRRC Contribution No. 88-26. Agriculture Canada, Whitehorse, Yukon. 101 pages with maps.

Sooter, C. A. 1942. Duck Hawk takes Short-eared Owl. Condor 44: 182.

Tacha, T. C., S. A. Nesbitt, and P. A. Vohs. 1992. Sandhill Crane (Grus canadensis). The Birds of North America Online. Edited by A. Poole. Cornell Lab of Ornithology, Ithaca, New York. http://bna.birds.cornell.edu/bna/species/ 031. (Accessed February 2012).

Therrien, J-F. 2010. Territorial behavior of Short-eared Owls, Asio flammeus, at more than $1000 \mathrm{~km}$ north of their current breeding range in northeastern Canada: evidence of range expansion? Canadian Field-Naturalist 124(1): 5860.

Village, A. 1987. Numbers, territory-size and turnover of Short-eared Owls Asio flammeus in relation to vole abundance. Ornis Scandinavica 18: 198-204.

Walker, D. A., M. K. Raynolds, F. J. A. Daniëls, E. Einarsson, A. Elvebakk, W. A. Gould, A. E. Katenin, 
S. S. Kholod, C. J. Markon, E. S. Melnikov, N. G. Moskalenko, S. S. Talbot, and B. A.Yurtsev. 2005. The Circumpolar Arctic vegetation map. Journal of Vegetation Science 16: 267-282.

White, C. M., N. J. Clum, T. J. Cade, and W. G. Hunt. 2002. Peregrine Falcon (Falco peregrinus). The Birds of North America Online. Edited by A. Poole. Cornell Lab of Ornithology, Ithaca, New York. http://bna.birds.cornell .edu/bna/species/660. (Accessed February 2012).
Wiggins, D. A., D. W. Holt, and S. M. Leasure. 2006. Shorteared Owl (Asio flammeus). The Birds of North America Online. Edited by A. Poole. Cornell Lab of Ornithology, Ithaca, New York. http://bna.birds.cornell.edu/bna/species/ 062. (Accessed February 2012).

Received 22 July 2011

Accepted 14 February 2012 